\title{
Wind Energy Potential for Electricity Production in Hatay, Turkey
}

\author{
Cansev Genç ${ }^{1 *}$, Abdulla Sakalli ${ }^{1}$,Ivaylo Stoyanov ${ }^{2}$, Teodor Iliev $^{2}$, Grigor Mihaylov ${ }^{3}$, and \\ Ivan Beloev ${ }^{2}$ \\ ${ }^{1}$ Iskenderun Technical University, Dept. of Industrial Engineering, Turkey \\ ${ }^{2}$ University of Ruse, 8, Studentska Street, 7017 Ruse, Bulgaria \\ ${ }^{3}$ University of Telecommunications and Post, 1 Acad. Stefan Mladenov Str., Bulgaria
}

\begin{abstract}
In this study, we examine Turkey's Hatay city and some of its districts (Belen, Antakya, Iskenderun, Samandağ) and we assessed the possibility of electricity production from wind power plants. The area of Hatay is $5559 \mathrm{~km}^{2}$ that is located in the southernmost part of Turkey and east of the Mediterranean Sea. The accumulated data obtained from BelenHatay wind speed data are shown. The seasonal cumulative probability distributions of wind speeds for Belen-Hatay are analysed in the paper. The wind speeds in summer are higher than in the other seasons. As a result, the Belen-Hatay region is a very favourable place in terms of wind and has high wind energy potential. In this region, the hourly wind speeds are higher than $5 \mathrm{~m} / \mathrm{s}$ and about $70 \%$ of occasions at $10 \mathrm{~m}$ height above ground level. It is also known that for nine months of the year, the average wind speeds are more than $5 \mathrm{~m} / \mathrm{s}$. On the other hand, average monthly wind energy productions are higher than $200 \mathrm{~W} / \mathrm{m}^{2}$ for eight months of the year.
\end{abstract}

\section{Introduction}

Renewable energy sources (RES) are becoming more relevant to the reduction of traditional fossil fuels and the continuous increase in energy demand. Wind energy is one of the most important and fast-growing RES, which has developed quite rapidly in recent years. That makes it possible to increase the competitiveness of the economy, protect the environment, and increase the security of electricity supply. Thus, technical and organizational solutions are being sought to meet the increased consumption and ensure reliable and quality electricity supply to consumers. Turkey has a high increase in energy demand in the last years in this regard. For example, in 2016 the country was able to meet only $26 \%$ of total energy demand from its local resources [9].

Turkey is surrounded by sea on three sides, with mountainous landforms, which contains combination of a wide variety of climate. The country has a favourable geographical position in terms of operating wind energy [1].The face of Turkey is 774815 $\mathrm{km}^{2}$ and it has a very long sea coastline, being the Black Sea in the north, the Marmara and

\footnotetext{
*Correspondingauthor:genccansev@gmail.com
} 
the Aegean Sea in the West, and the Mediterranean Sea in the South. Especially the Aegean, Marmara, and Eastern Mediterranean are favourable regions for wind potential [8].

In this study, we will examine Turkey's Hatay city and some of its districts (Belen, Antakya, Iskenderun, Samandağ) and we assessed the possibility of electricity production from wind power plants.

\section{Material and Methods}

The area of Hatay is $5559 \mathrm{~km}^{2}$, located in Southern and eastern Syria (Fig. 1) [5]. Located in the southernmost part of Turkey and east of the Mediterranean region, it is Turkey's major gateway to the Middle East geography [6]. Hatay's geographical coordinate system $35^{\circ} 49^{\prime} 31^{\prime \prime}-37^{\circ} 00^{\prime} 28^{\prime \prime}$ with K latitudes $35^{\circ} 44^{\prime} 03^{\prime \prime}-36^{\circ} 43^{\prime} 08^{\prime \prime} \mathrm{D}$ longitudes are between [5].

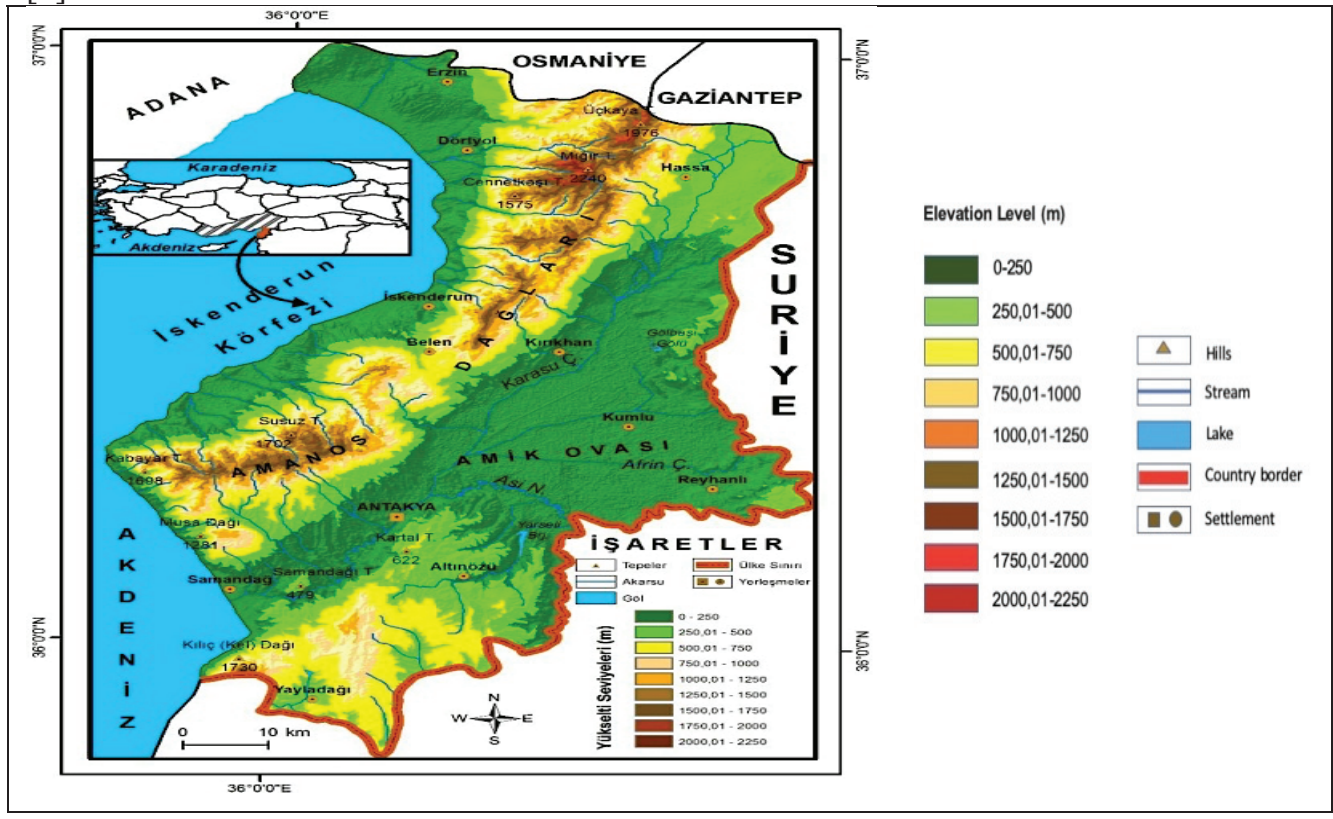

Fig. 1. Hatay location map

According to the information provided in [7], the total area of RES to be established in Hatay Province is $682.8 \mathrm{~km}^{2}$. New renewable energy capacities will be built on it with a total installed capacity of $3414000 \mathrm{MW}$ [5]. In the table. 1 shows the installed power of wind power plants (WPP) in the region of Hatay, Turkey.

Table 1. Hatay Wind Power Plants in Operation фop 2017 [10].

\begin{tabular}{|l|l|l|}
\hline Location & Wind Stations Name & Installed Power \\
\hline Hatay-Samandağ & SEBENOBA RES & $63.7 \mathrm{MW}$ \\
\hline Hatay-Belen & ATİK BELEN RES & $18 \mathrm{MW}$ \\
\hline Hatay-Belen & BELEN RES & $48 \mathrm{MW}$ \\
\hline Hatay-Belen & ŞENBUK RES & $65.8 \mathrm{MW}$ \\
\hline Hatay-Samandağ & ZIYARET RES & $76 \mathrm{MW}$ \\
\hline Hatay-Çerçikaya & ÇERÇİKAYA & $57 \mathrm{MW}$ \\
\hline Hatay-Şenköy & ŞENKÖY RES & $36 \mathrm{MW}$ \\
\hline & HATAY TOTAL & $\mathbf{3 6 4 . 5} \mathbf{M W}$ \\
\hline & HATAY/TURKEY \% & $\mathbf{5 . 6 2 \%}$ \\
\hline &
\end{tabular}


The total installed capacity amounts to $364.5 \mathrm{MW}$, and the relative weight of wind energy in the province compared to that of the country is $5.62 \%$.

\section{Results and Discussion}

The energy sector in Turkey uses many renewable energy sources, such as hydropower, geothermal energy, and increasing wind energy (Fig. 2). Renewable energy sources provide a large part of the country's electricity production. According to the Ministry of Energy and Natural Resources [2] in 2016, 12\% of Turkey's total primary energy supply (16.9 Mtoe) was met from renewable energy sources.

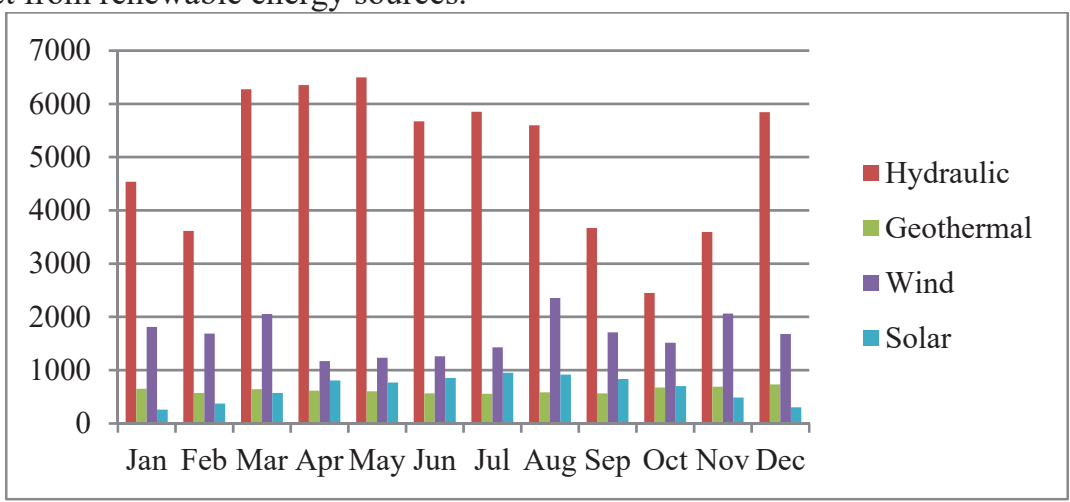

Fig. 2. Generated electricity from RES power plants in Turkey for 2018, GWh (Source: TETC, 2019)

The total amount of electricity produced in 2018 is respectively: hydraulic 59938GWh; geothermal - 7431 GWh; wind - 19949 GWh; solar - 7800 GWh.

The meteorological parameters that are of interest for the engineering activities related to renewable energy sources are wind (speed and direction); solar radiation; air temperature; air humidity; atmospheric pressure; precipitation.

On fig. 3 are shown the wind map of Turkey [3]. As shown in the figure, the Marmara, Aegean, and Eastern Mediterranean regions have high wind potential [3]. Balıkesir, Izmir, Çanakkale, Manisa, and Hatay are the cities with high wind potential in Turkey [4].

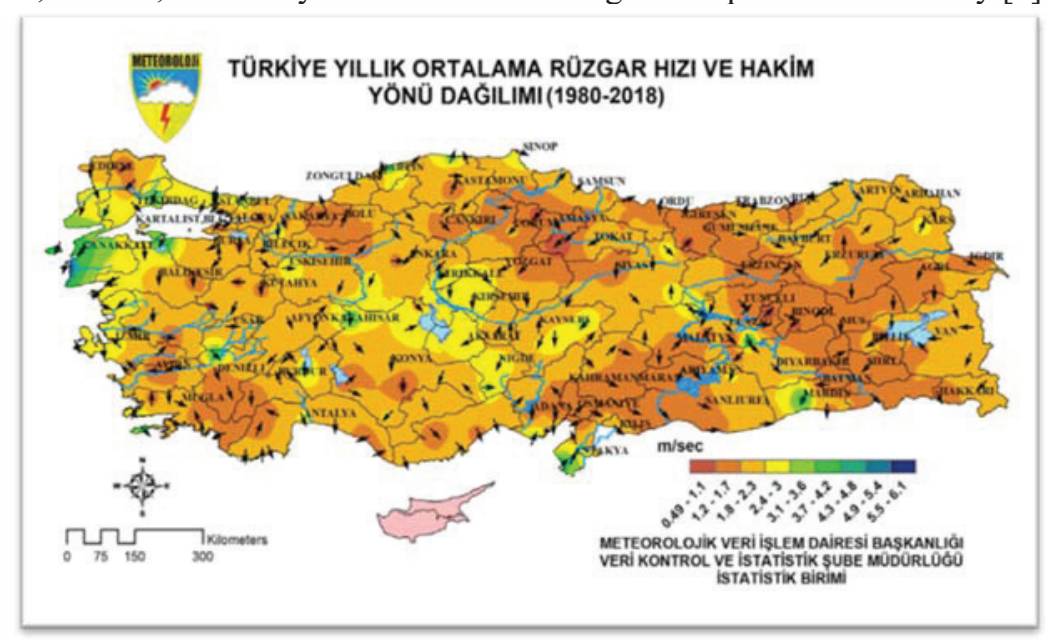

Fig. 3. Turkey's annual average wind speed and direction judge distribution (General Directorate of Meteorology). 
There are different types: theoretical potential - defined as the energy equivalent of the entire physically available resource; available technical potential - that part of the theoretical potential of the respective RES resource, the energy utilization of which is limited by technical and non-technical conditions (financial, legal and other conditions); available technical potential - that part of all available technical potential that can be utilized [11].

Wind energy is the kinetic energy of the wind, defined by the speed and density of the airflow. The theoretical potential is measured in $\mathrm{W} / \mathrm{m}^{2}$ earth surface. Many meteorological stations around the world measure wind speed and direction. Measurements are usually made at a height of $10 \mathrm{~m}$ as this height is accepted as a standard in this field. Exceptions with other values of the measuring masts are also allowed. The wind speed is measured with an anemometer and its direction with a wind vane.

The criteria based on which the energy potential for wind energy production is assessed are its direction and its average annual speed. The following figures show wind potential data in the Hatay region, Turkey.

It has been established that the most suitable areas for RES in the province are geographical locations Antakya-Samandağ and Belen [5]. A large part of the territory of the region falls within the zone of the technologically usable wind potential with an average annual speed of over $4 \mathrm{~m} / \mathrm{s}$. Summary data for cumulative probability distributions of wind speeds in Hatay-Belen are shown in Fig. 4.

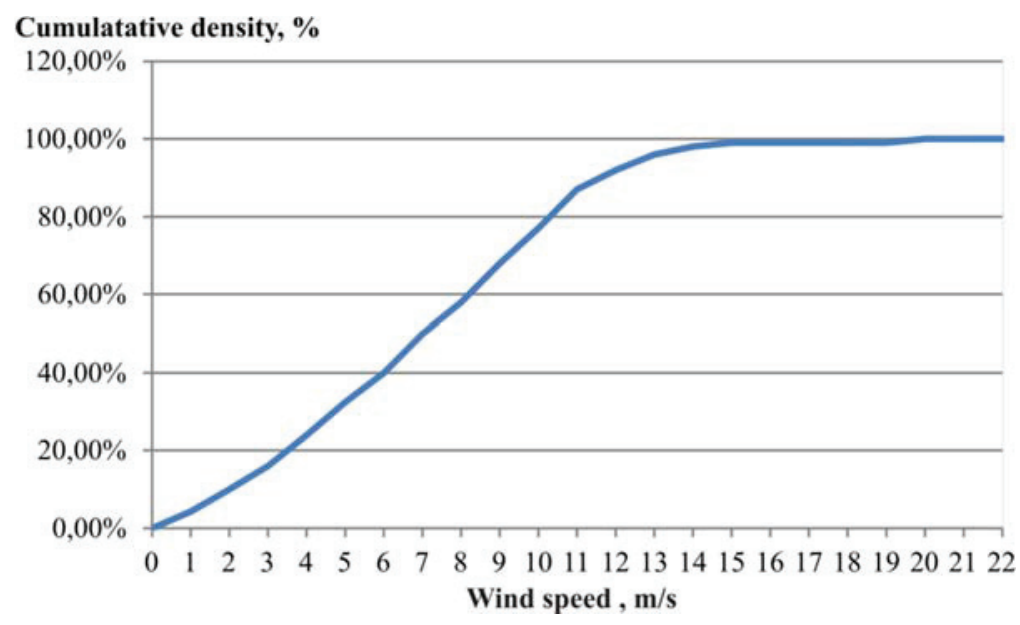

Fig. 4. Yearly cumulative probability distributions of wind speeds

The wind speed during the summer months in the area of Hatay-Belen is higher than in the other months of the year. In this region, a relatively high average wind speed of over 5 $\mathrm{m} / \mathrm{s}$ is observed for about $70 \%$ of the time at a height of $10 \mathrm{~m}$ above the ground. The average monthly wind power density is over $200 \mathrm{~W} / \mathrm{m}^{2}$ for most of the year [12]. The analysis of the data provides information that the Hatay-Belen region has an appropriate geographical location and meteorological data for the construction of wind energy installations.

Figure 5 displays the wind rose for Antakya (a) and Iskenderun region (b). This vector diagram expresses the statistic distribution for the wind of a given location for a certain period. From a statistical point of view, the wind rose is a circular cumulative diagram, the sectors of which are again the direction, and the levels at which the sectors are divided, give the percentage contribution of the speed categories in the respective direction. 


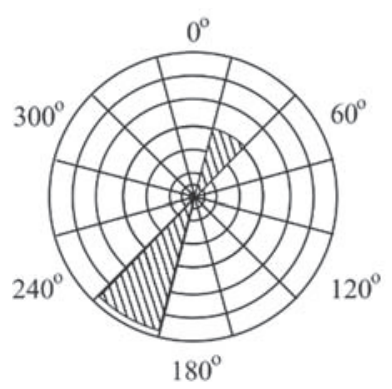

a)

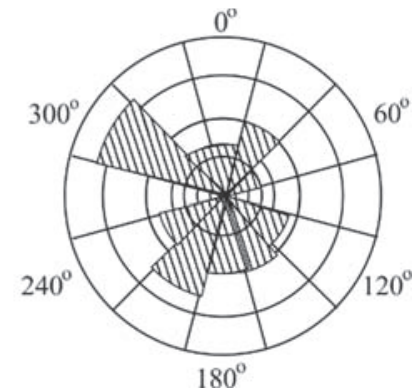

b)

Fig. 5. Wind roses for Antakya (a) and Iskenderun region (b).

The sectors of the diagrams correspond to the categories of the direction, ie. for the Antakya region the wind is in two characteristic directions - predominant south (about $30 \%$ ) and north (about 15\%), while for the Iskenderun region - the prevailing winds are from the west (about 20\%) and south (about 16\%). Determining the direction of the wind is the geographical position and relief of the earth's surface. The radial height of each sector is in percentages marked with dashed circles. Each sector is divided into parts of a different radial length, filled in different shades of gray. Each part corresponds to a certain speed category. The height of a sector gives the percentage of observations for which the wind is in the corresponding direction. The radial width of a part of a sector gives the percentage of all observations with the respective categories of direction and speed. The lowest are the percentages of the east winds. The analysis of the data shows that the prevailing winds are from the west and south. The average wind speed and the average power density for the regions of Antakya and Iskenderun are respectively $[8,12]$ :

- Antakya: $\mathrm{v}=7,6 \mathrm{~m} / \mathrm{s}, \mathrm{P}=580 \mathrm{~W} / \mathrm{m}^{2}$

- Iskenderun: $\mathrm{v}=4,4 \mathrm{~m} / \mathrm{s}, \mathrm{P}=650 \mathrm{~W} / \mathrm{m}^{2}$

The data witnesses that the regions of Antakya and Iskenderun are suitable for the construction of wind energy plants.

On fig. 6 are shown the wind rose for Hatay's District Samandağ.

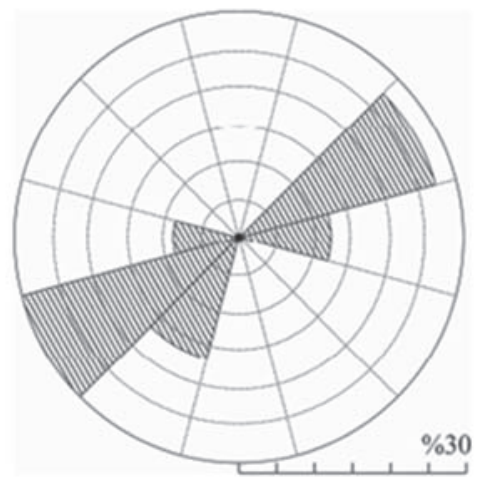

Fig. 6. Samandağ's Wind Rose [13].

The analysis of the diagram shows that for most of the year the prevailing wind direction for the Samandağ region is from the southwest $(30 \%)$ and the northeast $(27 \%)$. The lowest are the percentages of the northwest $(0.4-0.5 \%)$ and southeast winds $(0.6-0.7 \%)$.

In Fig. 7 is presented a histogram of wind speed in the Samandağ region. 


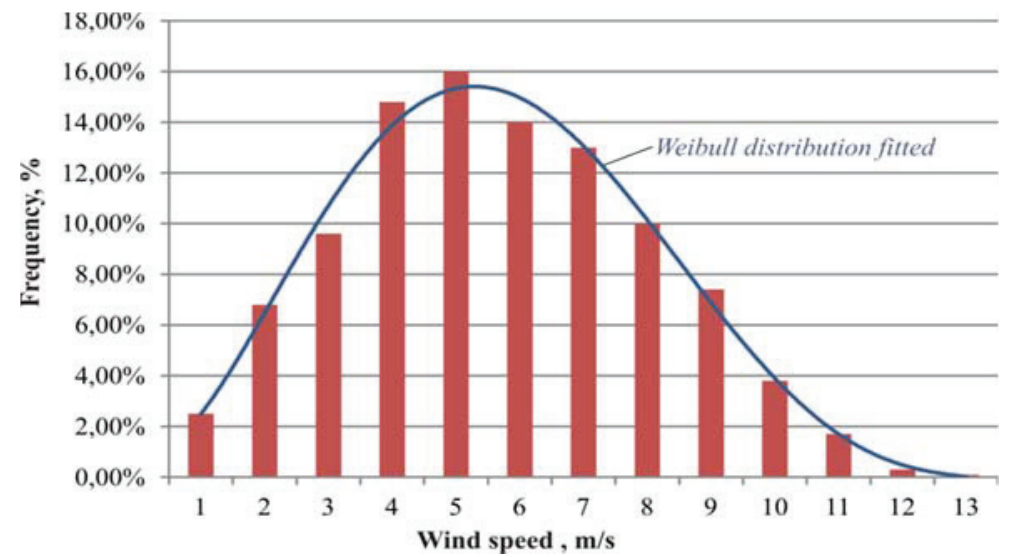

Fig. 7. Wind speed distribution Samandağ's.

The winds with speeds of 4 and $5 \mathrm{~m} / \mathrm{s}$ have the highest frequency - about $15 \%$ and $16 \%$, respectively. Over $80 \%$ of the cases have winds with a speed over $4 \mathrm{~m} / \mathrm{s}$, ie. falls within the zone of technologically usable wind potential. The average wind speed: $5.27 \mathrm{~m} /$ $\mathrm{s}$ for the height of the wind generator mast $10 \mathrm{~m}$, and the average power density: $143 \mathrm{~W} / \mathrm{m}^{2}[13]$.

Confirmation of relatively good conditions for electricity production in the region of Hatay, Turkey is also the presence of good practices in the area. The following larger wind farms have been installed and are operating in the Hatay area [14, 15, 16, 17]: Belen WPP with an installed power of $48 \mathrm{MW}$; Şebenoba WPP with 10 turbines by $3 \mathrm{MW}$ and 15 turbines by $2 \mathrm{MW}$. The total nominal power $60 \mathrm{MW}$; Çerçikaya WPP with total nominal power 57 MW; Ziyaret WPP with 76 MW installed capacity; Şenbük WPP with total nominal power $38 \mathrm{MW}$; Şenköy WPP (RES) nominal power of $35 \mathrm{MW}$.

\section{Conclusions}

Possibilities for the construction of wind energy recovery facilities in the Hatay region, Turkey has been investigated. It has been established that the region has suitable geographical and climatic conditions. The analysis of the statistical information on the wind distribution, the average speed, and the wind density shows that in over $80 \%$ of the year wind speeds above $4 \mathrm{~m} / \mathrm{s}$ are observed at a height of $10 \mathrm{~m}$ above the surface. The referenced wind usually used is 10 meters, but the calculations consider wind power and direction at turbine height. The wind speed in summer is higher than in other seasons. As a result, it has been found that the province of Hatay is suitable for the development of wind energy and in support of this are the available good practices with built wind power.

This paper including some part of the Master's Degree Thesis of Cansev Genç.

\section{References}

1. H. Soğukpınar, İ. Bozkurt, Wind energy use in Turkey. Europe and the world. It's potential and targets after 2013. Adiyaman University J. Eng. Sci.1(1),23-30 (2014)

2. Ministry of Energy and Natural Resources. https://www.enerji.gov.tr/.Acces date: $\underline{17.04 .2020}$ 
3. S. Durmuşoğlu, Energy policies of Turkey and its effects on international relations with neighboring countries (Master's thesis. Istanbul Commerce University), 111, (2015)

4. F. Sevilmiş, Synchronization of wind energy systems to the network (Ph.D. Thesis, Selçuk University Institute of Science), 216 (2016)

5. E. Özşahin, Ç. Kaymaz, A GIS Analysis of the Selection of the Location of Wind Energy Plant (WEP) Installation: Sample of Hatay. J.TUBAV Sci.6(2), 1-18 (2013)

6. H. Yumuşak, The impact of geographical location on tourism: instances of Hatay. In international West Asia Congress of Tourism (IWACT'17) the Book of full-text. 184196 (2017)

7. General Directorate of Renewable Energy Hatay Province Wind Resource Information http://www.eie.gov.tr/YEKrepa/HATAY-REPA.pdf.

8. M. Bilgili, B. Şahin, A. Kahraman, Wind energy potential in Antakya and Iskenderun regions, Turkey. Renewable Energy, 29(10), 1733-1745 (2004)

9. Republic of Turkey Ministry of Environment and Urbanization. http://mavikart.cevre.gov.tr/en

10. TWEA - Turkey Wind Energy Association. Turkey Wind Energy Statistics Report. (2017)

11. Terziev, A. K. Analysis of the terrain specifics and roughness factor on the wind shear over complex terrains. Paper presented at the IOP Conference Series: Materials Science and Engineering, 595(1) doi:10.1088/1757-899X/595/1/012043, (2019)

12. B. Şahin, M. Bilgili, Wind characteristics and energy potential in Belen-Hatay, Turkey. Int. J. Green Energy, 6(2), 157-172 (2009)

13. S. Ersöz, The analysing of electric production potential originating from wind and sun in Turkey. Marmara University, Institute of Science, Electrical Education Department Master's Thesis, 137 (2010)

14. Belen Wind Power Plant. https://www.enerjiatlasi.com/ruzgar/atik-ruzgar-enerjisisantrali.htmlAcces date: 17.04 .2020

15. Wind farm name: Şebenoba https://www.thewindpower.net/windfarm en_6086_sebenoba.phpAcces date: 17.04 .2020

16. Çerçikaya Wind Power Plant. https://www.enerjiatlasi.com/ruzgar/cercikayares.htmlAcces date: 17.04.2020

17. Ziyaret wind farm. https://www.thewindpower.net/windfarm en 15992 ziyaretres.phpAcces date: 17.04 .2020 